\title{
Students' Pedagogical Preferences in the Delivery of IT Capstone Courses
}

\author{
Kathy Lynch \\ Monash University, Australia
}

kathy.lynch@sims.monash.edu.au

\author{
Annegret Goold \\ Deakin University, Australia
}

agoold@deakin.edu.au

\author{
Jenny Blain \\ Ninox Solutions, Australia
}

jennyb@ninoxsolutions.com.au

\begin{abstract}
Capstone courses are used extensively in teaching information technology to expose students to realistic, work-like situations, though in a controlled environment. The value of the experiences the student engages in, and the skills and knowledge they develop are not questioned, as they are accepted as a beneficial precursor to professional work. The pedagogical methods used to deliver capstone courses vary across academic programme, institution, country and culture. The research explores information technology students' preferences for the delivery of capstone projects from three different pedagogical delivery approaches and suggests that students want a certain level of anonymity, but at the same time they want direction and assistance when they determine they require it. Emerging from the findings are several recommendations that developers of capstone projects and courses may wish to address.
\end{abstract}

Keywords: capstone projects, information technology education, experiential learning

\section{Introduction}

Final-year industry projects are the capstones of many academic information technology programs across the globe. These projects give students the opportunity to develop, refine, and evaluate their technical knowledge and skills in work-like situation, and work in teams in preparation for their future professional employment. The experience of students undertaking a worklike course is not new. Educationalist Franklin Bobbitt (1971) argues that education is "coming to realize the need of work-activities as the only possible normal method of preparing for the work of the world" (Bobbitt, 1971, p. 20).

Within the information technology (IT) domain, capstone projects prepare students for the workforce by solidifying discipline skills and knowledge, team skills and collaborative experiences in

Material published as part of this journal, either on-line or in print, is copyrighted by Informing Science. Permission to make digital or paper copy of part or all of these works for personal or classroom use is granted without fee provided that the copies are not made or distributed for profit or commercial advantage AND that copies 1) bear this notice in full and 2) give the full citation on the first page. It is permissible to abstract these works so long as credit is given. To copy in all other cases or to republish or to post on a server or to redistribute to lists requires specific permission from the publisher at Publisher@InformingScience.org a controlled environment. The level of control is related to the underpinning pedagogy of the teaching model used to deliver the course. There are numerous models of delivering capstone courses, each having their own deliverables, timelines, duration, control, emphasis, and resource allocation. In 
addition, the programmes under which these capstone projects operate have different entry requirements, underpinning philosophy, expectations and professional recognition.

No matter the origin of the academic program, the capstone course places a high level of demand and professionalism on the student, and is pedagogically different from the standard courses within their program.

This paper reports on a study that explored the impact of the pedagogical model on a variety of aspects common to capstone courses. Participants in the study were enrolled in an information technology capstone course in one of three tertiary institutions. Each of the institutions followed a different pedagogical approach in the delivery of their capstone course.

The paper is organized in the following manner. The first section presents a background into the educational underpinnings through an outline of what is meant by capstone course or project, a brief outline of four of the pedagogical models used to deliver capstone courses and an overview of experiential learning and team work as common strategies in the delivery of capstone courses. The second section describes the study conducted in three institutions that deliver capstone courses to their final-year information technology students. The third section presents the results of the study and a discussion of the findings. The final section contains several recommendations for developers of capstone courses together with ideas for further research in the field.

\section{Background}

Engaging students in work-like experiences, through simulated and authentic learning environments are commonplace in educational settings of today. The crux of this model of learning is not new, it is evident as far back in the teachings of Confucius in 450BC; "Tell me, and I will forget. Show me, and I may remember. Involve me, and I will understand". Educators have developed modern terms that have the same inference - that is, students will learn and understand if they have the opportunity to experience it. Learning-by-doing, reflection, experiential learning and collaboration are all part of the educational curricula today.

Employees in the IT workforce of the twenty-first century are required to work extensively in collaborative environments (Townsend, DeMarie \& Hendrickson, 1998). Educational institutions are expected to prepare their students to work effectively in this workforce and graduating students not only need to be academically capable but they also need to be able to work effectively as part of a collaborative team. One way of doing this is through exposure to project work (capstone courses). These learning opportunities simulate a project's life in a real-world context, giving the student an opportunity to, as Confucius stated, 'understand'.

The capstone projects are delivered with an emphasis on team work and collaboration, and are delivered using one of several pedagogical models. Each of these models is briefly presented in the following sections.

\section{Capstone Projects}

Capstone projects have been reported to be a cumulative and integrating experience (Clear, Goldweber, Young, Leidig \& Scott, 2001), and should be "both a synthesis - reflection and integration - and a bridge - a real-world preparatory experiences, (...) (with) emphasis on integration, experiential learning, and real-world problem solving" (Kerka, 2001, p. 1). In an information technology discipline, they synthesise "the basic elements of computer science with the basic skills of communication (both oral and written) and interpersonal relationships (.....) project planning and organisation" (Fuelling et al, 2003). Capstone projects allow for "recursive spiral of knowledge development" (Kolb \& Kolb, 2003, p. 25). 
Capstone courses are often delivered using different pedagogical approaches and resources. However, they have in common the aspect of learning through experience in preparing the students for entry into early career positions. The projects themselves vary from stand-alone or personal computer and information systems, networked solutions, mobile phone/digital assistant systems, multimedia applications and web-based information systems. The outcome of these projects depends on fulfilling the requirements of the client and also on fulfilling the requirements of the course and the academic staff. More importantly, the focus is process driven rather than product driven.

As stated above, there are differences between IT capstone courses across institutions, nevertheless, according to Kerka, they have the following objectives in common:

- "to provide students an opportunity to synthesise knowledge from formal and informal learning and apply it to contemporary issues in the field

- to help prepare students for a successful career by providing experiences that enhance their labour market advantage

- to increase students' understanding of the big picture, including ethical and social issues related to the field

- to help students understand the relevance of theory and research to practice." (Kerka, 2001:1).

Experiential learning is central to the development and delivery of capstone projects, regardless of the type of institution and their underpinning pedagogy for the IT capstone course delivery,

Experiential learning stems from John Dewey's work on theory of experience and is "the process whereby knowledge is created through the transformation of experience. Knowledge results from the combination of grasping and transforming experience" (Kolb, 1984, p. 41). Kolb and Kolb state that there are a number of modes of gaining experiences. These modes are Concrete Experience (CE), Abstract Conceptualization (AC), Reflective Observation (RO) and Active Experimentation (AE) (Kolb \& Kolb, 2003, pp. 5-6), and are relevant in understanding student experiences, approaches and acceptance of capstone projects.

To gain the most benefit from experiential learning, a student needs to be exposed to a balance of the four modes. This balance can be attained through continually experiencing, reflecting, thinking, and acting throughout the learning experience. Kolb and Kolb's four model model is consistent with Dewey (Dewey, 1934) "nothing takes root in mind when there is no balance between doing and receiving" (Dewey, 1934, p. 45). Add to this, the element of reflection-in-action (as introduced by Schon, 1983), and Keeton, Sheckley and Griggs's (2002) action/reflection integration - they all deepen the learning from experience.

According to Kolb and Kolb, experiential learning is not only related to the learning of knowledge and skills, but to the total experience encountered during the learning process. This includes the social and physical environment. They define the social and physical space as "making space for students to take control of and responsibility for their learning can greatly enhance their ability to learn from experience" (Kolb \& Kolb, 2003, p. 27). These come with their own challenges, but when this is accepted as a learning situation "people grow best where they continuously experience an ingenious blend of challenge and support" (Kegan, 1994, p. 42).

\section{Team Work and Collaboration}

Formation of effective collaborative teams is the essence of projects in many information technology capstone courses. An understanding of collaboration and acquisition of the skills required to work collaboratively are essential to the success of the project. The word collaboration can be traced back to the late $19^{\text {th }}$ century (Merriam-Webster, n. d.). It comes from the Latin word col- 
laboratus - to labour together. Over the past two decades, the word collaboration appears to have become a buzz word, particularly in the IT field. Graduating IT students are expected to be able to effectively collaborate with their team members to produce efficient and timely results. The IT professional now, more than ever, needs to be very competent and confident in their ability to work collaboratively in a team.

Roschelle and Teasley (1991) suggest that collaboration involves "a coordinated, synchronous activity that is the result of a continued attempt to construct and maintain a shared conception of a problem.... [and involves the] ...mutual engagement of participants in a coordinated effort to solve the problem together". Working in a collaborative team is not easy, though with experience and continuity it does become easier to do so and the rewards are worthwhile (Schrage, 1990, p. $34)$.

Exposure to capstone projects/courses emphasising experiential learning gives students a real experience in working in a collaborative effort to complete a specific project deliverable. Students can explore, experiment and investigate the workings of collaboration through participation in a capstone project, where their performance is challenged, mistakes can be made and opportunities for improvement are encouraged.

\section{Common Models of Delivery for Capstone Projects}

The manner in which a capstone course is delivered within an information technology programme often falls into one of the following four types of models:

- industry sponsored,

- studio,

- traditional,

- directed.

The models may vary in their implementation. The industry-sponsored model described here is based on what is described in the literature. The other three models - studio, traditional and directed - are those used in the three institutions of the study and the descriptions here relate to how they have been implemented in those institutions.

\section{The industry sponsored model}

This model varies across courses and institutions, but common to them is that final year students attend extended period of time as 'interns' in the workforce. This is usually as fulltime employees over 20 to 40 weeks duration. Placement is with an industry partner whom will subsequently employ graduates from these or similar courses. The students working within these internships take on the tasks, roles and responsibilities of an early career employee in the company. The academic requirements of the students undertaking an industry-based learning course are usually ill-defined and negotiated between the industry employee and the university (see Effenberg, 1996).

\section{The studio model}

This model is still in its infancy in the information technology domain though it is common in arts and architecture. The studio model is based on students working beside experts and mentors in a collaborative manner to engage the students in the learning process. During the capstone course, weekly meeting and work times are scheduled together with the twenty-four hours a day and seven-day-a-week availability of professional facilities and space. Students form teams of four to six and they work with a tutor and an academic on real projects sourced from within the community. The projects run for two semesters in length. The deliverables are defined but their 
specific content is flexible and is determined by the development approach taken and the requirements of the client (see Carbone, Lynch, Arnott and Jamieson, 2000).

\section{The traditional model}

This model is the most common delivery mechanism found within university settings. Students form teams - either large (ten to fifteen), or smaller teams (four to seven) and they have an academic staff member responsible for sourcing and allocating projects with another academic staff member to supervise them. The projects may have an outside client but they are more commonly sourced from within the university. The project deliverables are often clearly defined and there is limited technical and mentor support from faculty with no scheduled classes (see Goold \& Horan, 2002).

\section{The directed model}

This model is very common in the vocational (technical) sector of education. Capstone projects involving students teams of four to six are conducted in the final year of the two-year program. The student teams are supported by two academic staff members- one who has expertise in project management and the other who provides technical support. The technical academic works closely with the team for three to seven hours each week. Each team is provided with a clearly defined set of project requirements, milestones and deliverables.

\section{The Study}

There were two main aims of the research. The first aim was to investigate aspects of students' pedagogical preferences while participating in information technology capstone courses. The second aim was to identify commonalities and differences between these preferences with respect to three specific teaching approaches. Both of these aims were important to the researchers. It was expected that the outcomes of the research would provide an understanding of pedagogical approaches other than their own in delivering capstone courses and lead to further refinement of their particular teaching approach.

A quantitative methodology was adopted involving a single, anonymous and voluntary survey questionnaire.

\section{Participants}

Participants for the study were selected from final stage information technology students enrolled in a specific capstone course at one of three participating institutions during Semester 2, 2002.

Students from Monash University and Deakin University, and students from Holmesglen Institute of TAFE (technical and further education) volunteered to participant in the research. Overall one hundred and ninety-six students participated in the study.

The three institutions differ in the way they deliver their IT capstone course. Monash University uses the studio model, Deakin University follows the traditional model while Holmesglen Institute uses a directed model (see previous section). The three institutions also differ in other aspects of the capstone course such as resources, types of projects, team structures and assessment. Summaries are presented in Table 1, it should also be noted that the entrance requirement to a university program is more scholastic than that for entry into TAFE. At Holmesglen Institute students undertake their capstone course at the end of their second year, whereas the university students undertake their capstone project at the end of their third year. 
Table 1 Summary of the delivery models for the capstone projects across the three institutions.

\begin{tabular}{|c|c|c|c|}
\hline & $\begin{array}{l}\text { Studio } \\
\text { A Monash University }\end{array}$ & $\begin{array}{l}\text { Traditional } \\
\text { B Deakin University }\end{array}$ & $\begin{array}{l}\text { Directed } \\
\text { C Holmesglen Institute }\end{array}$ \\
\hline \multicolumn{4}{|l|}{ Course } \\
\hline $\begin{array}{r}\text { duration of } \\
\text { qualification }\end{array}$ & 3 years & 3 years & 2 years \\
\hline course name & Third-year Studio & Computing Project & Project \\
\hline course duration & 26 weeks & 13 weeks & 18 weeks \\
\hline timetabled hours/week & 4 & 0 & 9 \\
\hline $\begin{array}{l}\text { credit value (\%age of } \\
\text { fulltime student load) }\end{array}$ & $25 \%$ & $25 \%$ & $50 \%$ \\
\hline \multicolumn{4}{|l|}{ Resources } \\
\hline physical workspace & $\begin{array}{l}\text { dedicated tailor-made } \\
\text { design }\end{array}$ & students find their own & $\begin{array}{l}\text { scheduled laboratories } \\
\text { and meeting rooms }\end{array}$ \\
\hline electronic workspace & $\begin{array}{l}\text { dedicated shared and } \\
\text { individual space }\end{array}$ & $\begin{array}{l}\text { limited supplied, above } \\
\text { this students find their } \\
\text { own }\end{array}$ & $\begin{array}{l}\text { dedicated shared and } \\
\text { individual space }\end{array}$ \\
\hline $\begin{array}{r}\text { software and IT } \\
\text { services }\end{array}$ & $\begin{array}{l}\text { standard university } \\
\text { software, course spe- } \\
\text { cific software, addi- } \\
\text { tional considered on a } \\
\text { case-by-case basis, } \\
\text { moderate technical sup- } \\
\text { port }\end{array}$ & $\begin{array}{l}\text { standard university } \\
\text { software, limited tech- } \\
\text { nical support }\end{array}$ & $\begin{array}{l}\text { course specific software, } \\
\text { limited technical support }\end{array}$ \\
\hline computer hardware & $\begin{array}{l}\text { dedicated high end } \\
\text { hardware, wireless and } \\
\text { laptops }\end{array}$ & $\begin{array}{l}\text { standard computer } \\
\text { laboratories }\end{array}$ & $\begin{array}{l}\text { standard computer labo- } \\
\text { ratories }\end{array}$ \\
\hline computer peripherals & $\begin{array}{l}\text { numerous, off site loan, } \\
\text { (scanners, zip drives, } \\
\text { digital cameras, web } \\
\text { cams, CD writers) }\end{array}$ & $\begin{array}{l}\text { students organise their } \\
\text { own }\end{array}$ & $\begin{array}{l}\text { numerous (scanners, } \\
\text { digital cameras, CD } \\
\text { writers) }\end{array}$ \\
\hline \multicolumn{4}{|l|}{ Projects } \\
\hline clients & external & internal and external & internal and external \\
\hline team size & $4-8$ & $9-13$ & $4-5$ \\
\hline $\begin{array}{r}\text { co-ordinator } \begin{array}{r}\text { (admini- } \\
\text { stration) }\end{array} \\
\end{array}$ & Course coordinator & Course coordinator & Course teacher \\
\hline project supervisors & $\begin{array}{l}\text { Course academics and } \\
\text { Course tutors }\end{array}$ & Course academics & $\begin{array}{l}\text { Course teacher - techni- } \\
\text { cal } \\
\text { Course teacher - project } \\
\text { management }\end{array}$ \\
\hline $\begin{array}{l}\text { project lead- } \\
\text { ers/manager }\end{array}$ & Student & Student & Student \\
\hline \multicolumn{4}{|l|}{ Assessment } \\
\hline Deliverables: & $80 \%$ & $100 \%$ & $100 \%$ \\
\hline Product & $60 \%$ & $60 \%$ & $25 \%$ \\
\hline Process & $20 \%$ & $40 \%$ & $75 \%$ \\
\hline Examination & $20 \%$ (interview) & none & none \\
\hline $\begin{array}{r}\text { Total group assessment } \\
\text { Total individual as- } \\
\text { sessment }\end{array}$ & $\begin{array}{l}65 \% \\
35 \%\end{array}$ & $\begin{array}{l}100 \% \\
\text { none }\end{array}$ & $\begin{array}{l}75 \% \\
25 \%\end{array}$ \\
\hline
\end{tabular}




\section{Data Collection Instrument and Method of Analysis}

Quantitative data was captured using a paper-based survey questionnaire designed by the researchers. It consisted of 30 closed questions. The data was collected during the final weeks of the capstone course in each of the participating institutions. Participation in the research was voluntary and those who participated did so anonymously.

The participants were asked to select a point on a seven-point scale that best represented their preference or agreement to a given statement. A 'not sure' option was at one end of the continuum and a mid-point signified no preference. Demographic data was also collected but is not reported in this paper.

The survey questions were devised around several themes. The themes were not clearly distinguishable and there was some overlap in the types of questions asked where wording was open to interpretation. Nevertheless the themes were:

- Learning process

- Satisfaction with the process and outcomes

- Deliverables

- Project management

- Supervision.

The questionnaire responses were transposed into numeric data and each response was identified as to the institution from which it originated. The data was imported into a statistical package (SPSS). Analysis of Variance (ANOVA) techniques were applied to the data to highlight any patterns and significant differences between the three institutions. One-way analysis of variance was conducted so that the mean scores between more than two independent groups could be compared. This was done to show if there were any significant differences. A Tukey HSD ("Honestly Significantly Different") procedure was conducted on the data to establish where the significant differences were.

\section{Results}

One hundred and ninety-six students from the three institutions participated in the study.

An Analysis of Variance (ANOVA) was conducted on the responses to the thirty questions, using the three institutions as the independent variable. This analysis found that six of the questions produced statistically significant differences at the 0.05 level of significance. Results for these six questions are presented in Table 2 and are the focus of the discussion.

A Tukey HSD procedure was conducted to indicate exactly where the differences among the student cohorts appear. These were found to be:

Q7, (Having well defined objectives) Group A (studio) is significantly different from Group C (directed), and Group B (traditional) but Groups A and B are not significantly different

Q8, (Having timetabled group work session) Group B (traditional) is significantly different from Group C (directed)

Q13, (Having easy access to staff for help when the group feels help is needed) Group A (studio) is significantly different from both Group B (traditional) and Group C (directed)

Q14, (Having a defined meeting procedure for group meetings) Group A (studio) is significantly different from Group C (directed) 
Table 2 ANOVA results

\begin{tabular}{|c|c|c|c|c|c|}
\hline Question & & $\mathbf{N}$ & Mean & $\begin{array}{l}\text { Std. } \\
\text { Devia- } \\
\text { tion }\end{array}$ & $\begin{array}{l}\text { F ratio } \\
(F=F(d f / d f 2)\end{array}$ \\
\hline \multirow[t]{4}{*}{7 Having well defined objectives } & A & 47 & 2.04 & 1.250 & \multirow[b]{4}{*}{$\begin{array}{l}\mathrm{F}=5.256(2 / 190) \\
\mathrm{p}<=0.05\end{array}$} \\
\hline & $\mathrm{B}$ & 56 & 2.02 & 1.258 & \\
\hline & $\mathrm{C}$ & 90 & 1.52 & .851 & \\
\hline & Total & 193 & 1.79 & 1.108 & \\
\hline \multirow[t]{4}{*}{8 Having timetabled group work session } & A & 46 & 2.72 & 1.486 & \multirow[b]{4}{*}{$\begin{array}{l}\mathrm{F}=3.606(2 / 183) \\
\mathrm{p}<=0.05\end{array}$} \\
\hline & B & 56 & 2.13 & 1.322 & \\
\hline & $\mathrm{C}$ & 84 & 2.80 & 1.634 & \\
\hline & Total & 186 & 2.58 & 1.531 & \\
\hline \multirow[t]{4}{*}{$\begin{array}{l}13 \text { Having easy access to staff for help } \\
\text { when the group feels help is needed }\end{array}$} & A & 47 & 2.34 & 1.356 & \multirow[b]{4}{*}{$\begin{array}{l}\mathrm{F}=8.438(2 / 190) \\
\mathrm{p}<=0.05\end{array}$} \\
\hline & $\mathrm{B}$ & 57 & 1.68 & 1.227 & \\
\hline & $\mathrm{C}$ & 89 & 1.52 & .906 & \\
\hline & Total & 193 & 1.77 & 1.169 & \\
\hline \multirow[t]{4}{*}{$\begin{array}{l}14 \text { Having a defined meeting procedure } \\
\text { for group meetings }\end{array}$} & A & 48 & 2.83 & 1.294 & \multirow[b]{4}{*}{$\begin{array}{l}\mathrm{F}=3.388(2 / 188) \\
\mathrm{p}<=0.05\end{array}$} \\
\hline & $\mathrm{B}$ & 55 & 2.24 & 1.333 & \\
\hline & $\mathrm{C}$ & 88 & 2.23 & 1.468 & \\
\hline & Total & 191 & 2.38 & 1.405 & \\
\hline \multirow[t]{4}{*}{$\begin{array}{l}17 \text { The team project made efficient use } \\
\text { of my time }\end{array}$} & A & 43 & 2.63 & 1.363 & \multirow[b]{4}{*}{$\begin{array}{l}\mathrm{F}=4.271(2 / 176) \\
\mathrm{p}<=0.05\end{array}$} \\
\hline & B & 53 & 2.72 & 1.657 & \\
\hline & $\mathrm{C}$ & 83 & 2.05 & 1.333 & \\
\hline & Total & 179 & 2.39 & 1.470 & \\
\hline \multirow{4}{*}{$\begin{array}{l}25 \text { The experience gained from the pro- } \\
\text { ject will be useful for my future em- } \\
\text { ployment }\end{array}$} & A & 46 & 3.39 & 1.374 & \multirow[b]{4}{*}{$\begin{array}{l}\mathrm{F}=8.547(2 / 181) \\
\mathrm{p}<=0.05\end{array}$} \\
\hline & B & 53 & 2.77 & 1.683 & \\
\hline & $\mathrm{C}$ & 85 & 2.21 & 1.604 & \\
\hline & Total & 184 & 2.67 & 1.638 & \\
\hline
\end{tabular}

Where A is Monash/Studio, B is Deakin/Traditional and C is Holmesglen/Directed model 
Lynch, Goold, \& Blain

Q17, (The team project made efficient use of my time) Group B (traditional) is significantly different from Group C (directed)

Q25, (The experience gained from the project will be useful for my future employment) Group A (studio) is significantly different from Group C (directed).

\section{Discussion}

A one-way between-groups analysis of variance was conducted to explore the impact of pedagogical model on a variety of aspects common to capstone courses. Participants came from three different institutions, with each institution implementing a different model of delivering their IT capstone course. There was a statistically significant difference at the 0.05 level for six of the thirty questions/statements in the questionnaire. Four of the six questions (7, 8, 13 and 14) were directly related to the organizational structure or processes of the course. One question (17) was related to the team's use of personal time and Question 25 was related to the value of the experience for future employment. It is responses to these questions that are discussed here.

It was found that the students following the directed model for their IT capstone course differed statistically significantly in each of the six identified questions to the other students.

Q7: (Having well defined objectives) The directed (C) and the traditional (B) students had a greater preference for clearly defined deliverables than the studio (A) students, however, all groups showed a preference for clearly defined deliverables.

Due to the nature of the directed model, students follow a very guided and lock-step approach to their projects with revisions suggested and made under the guidance of an academic administrator or technical manager. The deliverables for the traditional students are set at a high level, but the details are not clearly defined, and the students tend to want expert guidance in planning and managing their projects. The studio students follow a learning-by-doing approach and are expected to derive the exact nature of the deliverable themselves. The findings indicate that all groups prefer more direction than what currently exists.

Q8: (Having timetabled group work session) The directed (C) and the studio (A) students seem to prefer the existing arrangements of timetabled sessions, however, the traditional (B) students, who do not have timetables sessions, tend to want them.

On one extreme of the three teaching approaches there is the directed model with weekly timetable team sessions, and on the other end of the scale, there is the traditional approach where the team meet according to their own arrangements. The studio model where timetabled sessions are allocated, but not necessarily adhered to, is the compromise. Alongside timetabled sessions comes the allocation of meeting space and resources, which could have had an impact on the traditional students' preference for scheduled meeting times.

Q13: (Having easy access to staff for help when the group feels help is needed) The directed (C) students tended to prefer closer academic supervision or access to staff than either of the other two groups.

Both the traditional and the studio students work more independently than the directed students and this is evident in the directed student having a greater preference for easy access to staff. Both the traditional and the studio students require this access intermittently or when they feel that they need it.

Q14: (Having a defined meeting procedure for group meetings) The directed (C) students seem to prefer clearly defined meeting procedures than the studio (A) students. 
Once again these are the two extremes of the teaching approaches. The directed students look to the teaching staff for guidance and setting of procedures, whereas the studio students take on the responsibility of developing their own.

Q17: (The team project made efficient use of my time) The directed (C) agree that the individual team members' time is used effectively during the project, however, the traditional (B) students tend to feel that their individual time is not used well by the team.

The differences here shadow the differences between the teaching models. The directed students are given more specific and directed instructions throughout the project, and are assisted with the 'when and how' requirements of each stage, with staff monitoring their time and task allocation. The traditional students are left more to their own devices with infrequent, if any, intervention from staff. The students in this group are expected to report on issues or to raise questions related to process and procedure. The directed students undertake their study in a vocationally focussed environment with a higher emphasis on technical skills and deliverables. Throughout the project the teaching staff act as senior project managers and senior technical managers. The students take their place in a team that is focussed on the outcome with the process being more highly directed from the academic staff. The traditional students undertake their study in a university environment where the emphasis is on process and reflection rather than outcomes. A considerable effort on the students' behalf goes into the development and evaluation of team processes. This may lead the students to undervalue the time spent in the project if they focus on the project delivery.

Q25: (The experience gained from the project will be useful for my future employment) The directed (C) students agree that the project experience would be useful for future employment, where as the studio (A) students do not agree with the same level of confidence.

This question highlights one of the greatest gaps between the models and the environment in which the capstone courses are delivered. The directed students study in an institution that is focussed on vocational outcome. Professional practice and technical skills are the predominate focus in their courses. The students perceive the project experience to be useful for their future employment as this is generally their expectation for the course. The studio students encompass a wide variety of career aspirations - their course leads on to higher levels in the academic hierarchy.

The remaining twenty-four questions did not produce any statistically significant differences, nevertheless they cannot be ignored as they add depth and reasoning to the study. The questions that stand out from the rest other than those that have already been reported, were Question 3 Knowing the type of material I am being expected to produce, and Question 6 Having group membership selected by the project supervisor. Q3 produced the lowest overall mean and standard deviation for the three groups, and Q6 produced the highest overall mean and standard deviation for the three groups. Overwhelmingly students, no matter the teaching approach require guidelines as to what is required. On the other hand, students' responses differ in the amount of flexibility and freedom they desire with the directed group of students preferring less flexibility than the studio group of students. The findings indicate that the traditional and studio groups of students tend to have a deeper understanding and aspiration for the wider opportunities in the workplace, than the directed group of students.

\section{Conclusion}

The research described in this paper has examined three approaches in the delivery of capstone courses and has attempted to compare students' pedagogical preferences in those courses. It appears that regardless of the teaching model and the cohort, students undertaking an IT capstone course prefer clearly defined deliverables. The specific details of these deliverables differs between the models - with the directed group of students preferring step-by-step instructions, and 
Lynch, Goold, \& Blain

the traditional and studio groups wanting varying levels of flexibility and freedom to determine their own.

The next stage of the research will be to reexamine the data and explore individual differences such as gender, age and culture or educational background.

At this stage a number of recommendations can be made. They are listed here as general recommendations for the delivery of an IT capstone course, regardless of the teaching approach taken.

The recommendations are as follows:

1. Clearly define top-level deliverables, though allow for discovery (and ambiguity) at a micro level.

2. Schedule regular team meetings with appropriate rooms and resources.

3. Provide ready access to staff as required.

These recommendations are consistent with the current literature on developing and delivering capstone courses.

\section{Acknowledgements}

The authors would like to thank Dr Selby Markham of Monash University, for his assistance with the statistical analysis, and Sharon Berman for her assistance in confirming information regarding Holmesglen Institute of TAFE.

\section{References}

Bobbitt, F. (1971). The curriculum. Boston: Houghton Muffin.

Carbone, A., Lynch, K., Arnott, D \& Jamieson, P. (2000). Introducing a studio-based learning environment into Information Technology. In Proceedings Australian Society for Educational Technology/Higher Education Research and Development Society of Australasia (ASET/HERDSA) Conference, (2-5 July, Toowoomba: Australia).

Clear, T., Goldweber, M., Young, F., Leidig, P \& Scott, K. (2001). Resources for instructors of capstone courses in computing. (Working Group Report ITiCSE 2001), SIGCSE Bulletin 33, 4, 93-113. Retrieved September, 2003 from http://portal.acm.org/citation.cfm?id=572135\&coll=Portal\&dl=ACM).

Dillenbourg, P., Baker, M., Blaye, A. \& O'Malley, C. E. (1996) The evolution of research on collaborative learning. Oxford: Elsevier.

Effenberg, W. (1996) An industry based learning program in information technology: Development and coordination. In Proceedings of ASCILITE 1996 conference, Adelaide. Retrieved October, 2004 from http://www.ascilite.org.au/conferences/adelaide96/papers/07.html

Goold, A. \& Horan, P. (2002). Foundation software engineering practices for capstone projects and beyond. In Proceedings of Software Engineering and Training, Covington Kentucky, February 2002, 140-146.

Fuelling, C., Lancaster, A., Kertstetter, M., Roth, R., Brown, W., Reidenbach, R \& Wongsawatgul, B. (2003). Computer science undergraduate capstone course. Technical Symposium on Computer Science Education Proceedings of the nineteenth SIGCSE technical symposium on Computer Science Education. Retrieved January, 2004 from http://portal.acm.org/citation.cfm?id=52998\&coll=ACM\&dl=ACM\&CFID=14722599\&CFTOKEN=4 $\underline{6190875}$

Keeton, M. T., Sheckley, B. G., \& Griggs, J. K. (2002). Efficiency and effectiveness in higher education. Dubuque, IA: Kendall/Hunt Publishing Company. 
Kegan, R. (1994). In over our heads: The mental demands of modern life. Cambridge, MA, Harvard Uni versity Press.

Kerka, S. (2001). Capstone experiences in career and technical education. Practice Application Brief No 16. Clearing house on Adult, Career, and Vocational Education. Retrieved November, 2003 from http://ericacve.org/docs/pab00025.pdf

Kolb, A. \& Kolb, D. (2003). Learning styles and learning spaces: Enhancing experiential learning in higher education. Academy of Management Learning and Education.

Kolb, D. (1984). Experiential learning: Experience as the source of learning and development. New Jersey: Prentice-Hall.

Merriam-Webster (n. d.) Online Dictionary. Retrieved October 52003 from http://www.m-w.com

Roschelle, J. \& Teasley, S. (1991). The construction of shared knowledge in collaborative problem solving. In C. O'Malley (Ed.), Computer Supported Collaborative Learning. Heidelberg: Springer Verlag.

Schon, D. (1983). The reflective practitioner. New York: Basic Books

Schrage, M. (1990). Shared minds: The new technologies of collaboration. New York: Random House.

Townsend, A., DeMarie, S. \& Hendrickson, A. (1998). Virtual teams: Technology and the workplace of the future. Academy of Management Executive, 12 (3), p. 17-29.

\section{Biographies}

Kathy Lynch is a senior lecturer in the Faculty of Information Technology at Monash University, Australia. Kathy has taught in secondary, vocational and tertiary institutions around Australia. Her teaching is in the areas of HCI, studio-based teaching, multimedia systems development, and web databases. Her current research interests encompass collaborative work, enabling and emerging technologies, HCI and education. She is undertaking a Doctor of Philosophy in Education, and has a Master in Business Systems (research), multiple Post Graduate Diplomas in IT and Education, and a Bachelor of Education (Secondary).

(http://www.sims.monash.edu.au/staff/klynch/).

Annegret Goold is a lecturer in the School of Information Technology at Deakin University, Australia. Prior to joining Deakin in 1993 she worked as a computer programmer, analyst, technical writer and trainer. She has a computer science degree, a research Master of Commerce and is currently completing a Master of IT Education which will lead to a PhD. At present she teaches introductory IT, software engineering and project management. She is also involved with supervising projects in the capstone course. Her research interests align with her teaching areas as well as in computer science education - particularly in online pedagogies and technologies and problem-based learning.

Jenny Blain (M Bus Sys, B Sc Ed, Dip IT, MACS) is a Director of Ninox Solutions, providing information systems consultancy services to the small to medium business sector. Jenny retains her long-term connection with and love of education through occasional part-time or sessional lecturing positions at a range of educational institutions, particularly focussing on offering a commercial perspective to collaborative projects with final year students. 